\title{
Short-term Results of Patients Presented to the Pediatric Emergency Department with Fever
}

\section{Çocuk Acil Servisine Ateş Şikayeti ile Başvuran Hastaların Kısa Dönem Sonuçları}

\section{(D) Ülkem Koçoğlu Barlas}

University of Health Sciences Turkey, Bağcılar Training and Research Hospital, Clinic of Pediatrics, Division of Pediatric Intensive Care Unit, İstanbul, Turkey

\section{Abstract}

Objective: The aims of this study were to investigate the general characteristics of the patients who presented to the pediatric emergency department with fever, to determine the relationship between the sociodemographic characteristics of the families and the admission to the emergency department, to investigate the relationship between the treatments administered and the duration of fever reduction, and to evaluate the impacts of fever on the life of the child and the family during the period after admitting to emergency department.

Method: The study group consisted of patients who presented to the pediatric emergency department with the complaint of fever between $5^{\text {th }}$ of March and 31st of May 2009 and whose measured axillary temperature was $38{ }^{\circ} \mathrm{C}$ and above. The physical examination of the patients was performed, treatment was arranged in accordance with their diagnoses and the information was obtained from the parents about the sociodemographic characteristics of the families. Parents who were reached after 7-10 days were asked questions about the duration of fever reduction, whether there was a need to apply to another health institution, the methods used to reduce the fever and whether the child attended school.

Results: Two hundred forty five patients were included in the study: however, as 17 parents could not be reached at the controls after 7-10 days, the study was completed using the data of 228 patients. $73.1 \%$ of the patients were admitted to our emergency department within the first 24 hours after the onset of fever. A total of 57 patients (23.3\%) were prescribed only antipyretic treatment, 181 (73.9\%) were prescribed antipyretic and antibiotic treatment, and seven $(2.9 \%)$ were treated as hospitalized. It was learned that 189 patients (82.8\%) had reduced fever while 39 patients (17.2\%) were admitted to a health institution again. The school absenteeism rate in children aged 7 years and over was $72.9 \%$.

Conclusion: We think that there should be time for the anxiety reduction and education of patients, who are admitted with fever, and their relatives even in busy emergency departments and we suggest that antibiotic treatment should be reduced, and symptomatic treatment should be given at the first admission.

\section{Öz}

Amaç: Çocuk acil servisine ateş şikayeti ile başvuran hastaların gene özelliklerinin incelenmesi, ailelerin sosyo-demografik özelliklerinin acil servise başvuru ile arasındaki ilişkinin saptanması, düzenlenen tedaviler ile ateşin düşme süresi arasındaki ilişkinin araştırıması ve ateşin acil servis başvurusu sonrasındaki dönemde çocuk ve ailenin yaşamına etkilerinin değerlendirilmesi amaçlanmıştır.

Yöntem: Çalışma grubu 5 Mart- 31 Mayıs 2009 tarihleri arasında çocuk acil servisine ateş şikayeti ile başvuran ve ölçülen aksiller ateş düzeyi $38^{\circ} \mathrm{C}$ ve üzeri olan hastalardan oluşmaktadır. Hastaların fizik muayeneleri yapılarak, tanılarına uygun tedavileri düzenlenmiş ve ebeveynlerden ailelerin sosyo-demografik özellikleri hakkında bilgiler alınmıştır. Yedi-10 gün sonra ulaşılan ebeveynlere ateşin düşme süresi, bu süreçte başka bir sağlık kuruluşuna başvurup başvurma gereksinimi olup olmadığı, ateşi düşürmek için kullanılan yöntemler ve çocuğun okula devamsızlık yapıp yapmadığı ile ilgili sorular sorulmuştur.

Bulgular: Çalışmaya 245 hasta dahil edilmiş, 7-10 gün sonraki kontrollerde 17 ebeveyne ulaşılamadığı için çalışma 228 hastanın verileri üzerinden tamamlanmıştır. Olguların \%73,1'lik kısmı ateş başladıktan sonraki ilk 24 saat içerisinde acil servisimize başvurmuştur. Toplam 57 hastaya $(\% 23,3)$ sadece antipiretik tedavi reçete edilirken, 181 hastaya $(\% 73,9)$ antipiretik ve antibiyotik tedavisi reçetelenmiş, yedi hasta $(\% 2,9)$ ise hastaneye yatırılarak tedavi edilmiştir. Verilen tedavi ile 189 hastanın $(\% 82,8)$ ateşinin düştüğü, 39 hastanın ise $(\% 17,2)$ tekrar bir sağlık kuruluşu başvurusu olduğu öğrenilmiştir. Yedi yaş ve üzeri çocuklarda okul devamsızlık durumu ise \%72,9 olarak saptanmıştır.

Sonuç: Biz, acil servisi yoğun sağlık kuruluşlarında dahi ateşle başvuran hasta ve hasta yakınlarının kaygılarını giderme ve eğitimi için vakit ayrılması gerektiğini düşünmekte, antibiyotik tedavisinin azaltııı ilk başvuruda semptomatik tedavi verilmesini önermekteyiz.

Anahtar kelimeler: Acil, antibiyotik, ateş, çocuk

Keywords: Antibiotic, children, emergency, fever

Address for Correspondence: Ülkem Koçoğlu Barlas, University of Health Sciences Turkey, Bağcllar Training and Research Hospital, Clinic of Pediatrics, Pediatric Intensive Care Unit, İstanbul, Turkey E-mail: ulkemkocoglu@yahoo.com ORCID: orcid.org/0000-0001-7445-5858 Received: 02.05.2020 Accepted: 08.07.2020

Cite this article as: Koçoğlu Barlas Ü. Short-term Results of Patients Presented to the Pediatric Emergency Department with Fever. Bagcilar Med Bull 2020;5(3):82-87

๑) Copyright 2020 by the Health Sciences University Turkey, Bagcilar Training and Research Hospital Bagcilar Medical Bulletin published by Galenos Publishing House. 


\section{Introduction}

Fever is one of the most frequent complaints that is encountered in children's emergency services. The two major reasons for this are that infectious diseases are seen more frequently in children due to the still-developing immune system in them and that fever in children still remains an important source of fear for their families (1).

Fever is most often caused by simple viral diseases that heal spontaneously. Other causes of fever include serious lifethreatening bacterial infections, collagen vascular diseases, neoplastic diseases, acute metabolic disorders or drugs used (2). Parallel to the high frequency of fever, antipyretics and antibiotics constitute the most frequently prescribed medication groups in pediatric age group. Improper use of antibiotics leads to the development of bacterial resistance while imposing an additional burden on the national economy $(3,4)$. In fact, in the United States of America (USA), approximately half of the antibiotics given to children have been reported to be given unnecessarily (5).

The aims of this study were to examine the general characteristics of patients admitted to the children's emergency services in a training and research hospital where the number of daily patient admissions is very high, to determine whether there was a relationship between the socio-demographic characteristics of families and the admission to the emergency room, as well as between the medication and time required to reduce fever and to evaluate the effects of fever on the lives of children and families during the period after admission to emergency service.

\section{Materials and Methods}

This study was conducted on 245 patients who aged between 31 days and 18 years and were admitted to Okmeydanı Training and Research Hospital children's emergency services with a complaint of fever and whose axillary fever was $38{ }^{\circ} \mathrm{C}$ or above between March $5^{\text {th }}$ and May 31st 2009. Ethics committee approval was obtained from ethics committee of the same hospital before the study. Due to the fact that 17 parents could not be reached for the evaluation between 7 and 10 days after the admission, 228 cases were included in the study. The physical examinations of the patients were performed, and the treatment schedules were arranged according to their diagnoses. Identification information (name-surname, gender, age) of the patients, history of admission to another health institution due to the current fever complaint, information regarding accompanying symptoms and complaints, time period between the onset of fever and the admission to the emergency room, the diagnoses and treatment schedules (antipyretic, oral antibiotics, intramuscular antibiotics, hospitalization), socio-demographic characteristics of families (mother's age, education and employment status, total number of individuals and children living in the family, number of rooms in the house, number of people sharing the room of the patient, smoking status of the family members), whether other family members had fever or any other complaints within past two weeks and whether the patient had a travel history within past two weeks were recorded. Parents were given standard education on the measurement methods of body temperature, methods to reduce fever, and arranged treatments, and they were contacted by phone between 7 and 10 days after the treatment. The time period for the fever to reduce during the existing disease (0-24 hours, $24-48$ hours, $48-72$ hours, $>72$ hours), whether they were readmitted to a health institution during the same disease condition, methods applied to reduce the fever and school absenteeism due to this particular disease were questioned.

\section{Statistical Analysis}

Number Cruncher Statistical System (NCSS) 2007 \& Power Analysis Sample Size (PASS) 2008 Statistical Software (Utah, USA) was used for the statistical analysis for the evaluation of the results. Besides descriptive statistical methods for the data (mean, standard deviation, frequency), the KruskalWallis test was employed to analyze quantitative data. Qualitative data were analyzed by the chi-square test. 95\% confidence intervals were calculated and a p-value lower than 0.05 was considered as statistically significant.

\section{Results}

One hundred thirty one $(53.5 \%)$ of our patients were male and $114(46.5 \%)$ were female. The mean age of the cases was found to be $59 \pm 46.78$ months. During the admission, the body temperature of the cases ranged between 38 and $40.5^{\circ} \mathrm{C}$ and the mean body temperature was $38.85 \pm 0.53$ ${ }^{\circ} \mathrm{C}$. The number of daily patient admissions to the hospital with fever complaints ranged between 1 and 5 (mean $=1.13 \pm 0.46$, median $=1$ ). The time between the onset of fever and admission to the emergency service was between 0 and 12 hours in 98 patients (40\%), between 12 and 24 hours in 81 patients (33.1\%), between 24 and 48 hours in 34 patients $(13.9 \%)$, between 48 and 72 hours in 22 patients (9\%), and 72 hours and above in 10 patients (4\%). 
While there were no additional complaints accompanying fever in 43 cases (18\%), 98 patients (40\%) reported one accompanying complaint, 67 patients $(27.3 \%)$ had two accompanying complaints, 36 patients $(14.7 \%)$ had three or more accompanying complaints. Additional complaints accompanying fever are listed in Table 1 and the diagnoses made in our patients are listed in Table 2.

The mean age of the mothers participated in the study was $31.05 \pm 6.36$ years (minimum-maximum $=18-50$ ). Of the mothers, 13 (5.3\%) were illiterate, 150 (61.2\%) were primary school, 27 (11\%) were secondary school, 43 (17.6\%) were high school and 12 (4.9\%) were university graduates. While

\begin{tabular}{lll} 
Table 1. Distribution of additional symptoms that \\
accompany fever & $\mathbf{n}$ & $\%$ \\
\hline Cough & 67 & 27.3 \\
Vomiting & 48 & 19.6 \\
Abdominal pain & 36 & 14.7 \\
Sore throat & 36 & 14.7 \\
Weakness & 31 & 12.6 \\
Headache & 26 & 10.6 \\
Anorexia & 23 & 9.4 \\
Diarrhea & 22 & 8.9 \\
Nasal flow & 20 & 8.2 \\
Nausea & 16 & 6.5 \\
Leg pain & 7 & 2.8 \\
Nasal congestion & 4 & 1.6 \\
Earache & 4 & 1.6 \\
Wheezing & 2 & 0.8 \\
Unrest & 2 & 0.8 \\
Dyspnea & 2 & 0.8 \\
Oral aphthae & 1 & 0.4 \\
Constipation & 1 & 0.4 \\
Eruption & & 0.4 \\
\hline
\end{tabular}

\begin{tabular}{lll} 
Table 2. Diagnoses & $\mathbf{n}$ & \% \\
\hline AVURI & 56 & 22.9 \\
Acute tonsillitis & 147 & 60 \\
Acute sinusitis + AOM & 10 & 4.1 \\
Pneumonia & 13 & 5.3 \\
Meningitis & 3 & 1.2 \\
Acute bronchitis & 1 & 0.4 \\
UTI & 6 & 2.4 \\
AGE & 7 & 2.9 \\
Bacteremia & 2 & 0.8 \\
\hline
\end{tabular}

AVURI: Acute viral upper respiratory infection, AOM: Acute otitis media, UTI: Urinary tract infection, AGE: Acute gastroenteritis
$194(79.2 \%)$ of the mothers were housewives, 51 (20.8\%) were working. The average number of adults living at home was $2.40 \pm 0.98$ (minimum-maximum $=1-8$ and median $=2$ ). The average number of children living at home was $2.02 \pm 0.98$ (minimum-maximum $=1-7$ and median $=2$ ). The total number of people living at home varied between three and 12, with an average of $4.43 \pm 1.45$ and a median of four infants. The number of rooms in the house ranged between one and six, with an average of $3.14 \pm 0.71$ and a median of three rooms. The number of individuals with whom the child shared his/her room ranged between zero and six, with an average of $1.44 \pm 0.96$ and a median of one. Seventy-four of the mothers $(30.2 \%)$ stated that there was an individual who had fever in the past two weeks in the family, and 76 mothers (31\%) stated they had an individual with a complaint other than fever in the last two weeks. Travel history was stated in twenty-three $(9.4 \%)$ families in the last two weeks. There were smokers in one hundred and forty-two families (58\%), while there were no smokers in 103 families (42\%).

We provided 57 patients $(23.3 \%)$ with only antipyretic treatment, 92 patients (37.6\%) with antipyretic and oral antibiotic treatment, and 89 patients (36.3\%) with antipyretic and intramuscular antibiotic treatment, and seven patients $(2.9 \%)$ were hospitalized and treated. Seven to 10 days later, 189 of the parents $(82.8 \%)$ that were reached by phone stated that their children's fever decreased with the treatment given, and 39 parents (17.2\%) indicated that they required to apply to a health institution again. Among these, treatment schedule was not changed in 19 patients $(48.7 \%$ ) (12 of the patients were in another institutions while seven of the patients were in the same institution). Ten patients (25.6\%) were given antipyretic treatment in addition to the ongoing antibiotic treatment (seven of them were in another institutions while three of them were in same institution), while in 10 patients (25.6\%), antibiotic treatment schedule was altered (in seven patients the antibiotic that was given was changed into another antibiotic and in three patients, antibiotic administration route was changed to intramuscular administration). Considering the duration of fever to reduce, fever was reduced within the first 24 hours in 82 children (35.9\%), within $24-48$ hours in 85 children (37.2\%), within 48-72 hours in 49 children (21.4\%), and over 72 hours in 12 children (5.2\%). The data regarding the followup controls that were performed after seven to 10 days later are indicated in Table 3 and alterations in treatment are given in Table 4 . 
In this study, no statistically significant relationship was found between the educational status of the mother and the time between the onset of fever and admission to the emergency service, as well as no significant relationship between the educational status of the mother and time required for fever to reduce $(p>0.05)$. There were no statistically significant relationships between the treatment given and the time to fever to reduce or the duration of additional complaints to alleviate $(p>0.05)$. On the other hand, a statistically significant relationship was found between the treatment given and the presence of additional treatment, that is, the requirement of the admission to another health institution $(\mathrm{p}<0.01)$. It was observed that children who were treated only with antipyretics were admitted to another health institution more often. There was no statistically significant difference between the

\section{Table 3. Findings detected in controls after 7-10 days}

\begin{tabular}{llll} 
& & $\mathbf{n}$ & $\%$ \\
\hline Time to reduce fever & $0-24$ hours & 82 & 36 \\
$\mathbf{n = 2 2 8}$ & $24-48$ hours & 85 & 37.3 \\
& $48-72$ hours & 49 & 21.5 \\
& $>72$ hours & 12 & 5.3 \\
Time to reduce accompanying & $0-24$ hours & 39 & 20.7 \\
symptoms & & & \\
& $24-48$ hours & 60 & 31.9 \\
$\mathbf{n = 1 8 8}$ & $48-72$ hours & 34 & 18.1 \\
& $>72$ hours & 55 & 29.3 \\
& Not & 19 & 27.1 \\
& 1 day & 13 & 18.6 \\
School absenteeism period & 2 days & 14 & 20 \\
$\mathbf{n = 7 0}$ & 3 days & 11 & 15.7 \\
& $\geq 4$ days & 13 & 18.6 \\
Peripheral cooling & + & 84 & 36.8 \\
$\mathbf{n = 2 2 8}$ & - & 144 & 63.2 \\
\hline
\end{tabular}

duration of fever to reduce and the number of people living at home $(p>0.05)$. There was no statistically significant relationship between pre-diagnosis and duration of fever to reduce $(\mathrm{p}>0.05)$.

\section{Discussion}

In the list of "distribution of the diseases in children within the last six months", which included the infants aged between zero and six years and was released in 2012 by Turkey Statistics Institute, revealed that the three most common diseases that could be seen along with fever were diarrhea, upper respiratory tract infections such as tonsillitis, pharyngitis and otitis media, and infectious diseases such as chickenpox (6). In the study conducted by Halıcıoğlu et al. (7), the most common etiological causes in children admitted to the emergency service due to fever were found to be respiratory infections and gastroenteritis. In our study, we found acute viral upper respiratory tract infections and upper respiratory tract infection diseases such as tonsillitis, sinusitis and otitis media as the highest disorders with a rate of $87 \%$ among the patients who were admitted to our emergency service. It is noteworthy that the majority of our patients were male in accordance with other studies (8).

In our study, we observed that $73 \%$ of the patients were admitted to the emergency room within the first 24 hours after the onset of fever. This might have resulted from that patients did not know the role of fever in the followup of the disease and the methods to reduce the fever, as well as the fact that they still saw the fever as an anxious condition $(9,10)$. In a study by Poirier et al. (11), people caring for children responded to a question about why they were afraid of fever as "due to risk of convulsion (32\%), risk of death (18\%) and risk of brain damage (15\%)". It can be

Table 4. Treatment schedule

Treatment

\begin{tabular}{|c|c|c|c|c|c|}
\hline & \multicolumn{3}{|c|}{ Treatment } & \multirow[b]{2}{*}{ Hospitalizec } \\
\hline & & Antipyretic & $\begin{array}{l}\text { Antipyretic }+ \text { oral } \\
\text { antibiotics }\end{array}$ & $\begin{array}{l}\text { Antipyretic + i.m. } \\
\text { antibiotics }\end{array}$ & \\
\hline \multirow{6}{*}{$\begin{array}{l}7-10 \text { days after } \\
\text { controls }\end{array}$} & Not & 36 & 75 & 70 & 7 \\
\hline & $\begin{array}{l}\text { Application to different health institutions, no } \\
\text { treatment changes }\end{array}$ & 3 & 4 & 5 & 0 \\
\hline & $\begin{array}{l}\text { Application to different health institutions, } \\
\text { antibiotics were given }\end{array}$ & 10 & 0 & 0 & 0 \\
\hline & $\begin{array}{l}\text { Application to different health institutions, } \\
\text { different antibiotics were given }\end{array}$ & 0 & 1 & 7 & 0 \\
\hline & Application to our hospital, no treatment changes & 3 & 1 & 3 & 0 \\
\hline & $\begin{array}{l}\text { Application to our hospital, i.m. transition to } \\
\text { antibiotic administration }\end{array}$ & 3 & 0 & 0 & 0 \\
\hline
\end{tabular}


thought that this situation can be reduced by increasing the education levels of the people who care for the child, in the conditions of our country, the educational levels of mothers. However, in our study, we could not find a statistically significant relationship between the educational status of the mother and the time period between the onset of fever and admission to the emergency service ( $p>0.05)$. In the study conducted by Şen Celasin et al. (8), it was found that there was no statistically significant relationship between the education status of the mother and the period during which the child stayed with fever. Bertille et al. (12), in their studies, found that as the education level of the parents increased, the rates of admission to the emergency services increased. All these results can suggest that regardless of the educational background, the anxiety experienced by mothers for their children is similar. Moreover, in our study, no statistically significant relationship was found between the educational status of the mother and the time required for fever to reduce $(\mathrm{p}>0.05)$.

According to the 2008 data of the Child Emergency and Intensive Care Association, $30 \%$ of all emergency admissions in our country was constituted by admissions to the child emergency services (13). The child emergency service in our hospital is a tertiary child emergency unit that serves families with different sociocultural characteristics in a wide region. According to the data of the Ministry of Health in 2017, it served approximately 180,000 patients within the first nine months of the year (14). It is pleasing for us that the fever of $82 \%$ of the patients who were admitted to our emergency service with a fever complaint reduced with the treatment given by us and they did not need to apply to another health institution. Moreover, it was observed that the treatment schedule of approximately $50 \%$ of the patients who applied to the health institution for the second time was not altered. However, the fact that the rate of antibiotic prescription was as high as $74 \%$ was also very thoughtprovoking. Although upper respiratory tract infections that do not require antibiotics are common in children, studies still show that children have been prescribed antibiotics at high rates for these diseases $(15,16)$. Among the drugs prescribed to outpatients in our country, antibiotics maintain their first place $(17,18)$. We think that one of the reasons for the high rate of antibiotic prescription in our study was that rapid diagnostic tests for streptococcal infections and diagnostic tests that detected specific viral pathogens such as influenza were not initiated to be used during the study period. We did not find a statistically significant relationship between the treatment given in our study and either the time required for fever to reduce or the period of reduction of additional complaints ( $p>0.05)$. However, there was a significant relationship between the treatment given and receiving additional treatment, that is, re-applying to a healthcare institution $(\mathrm{p}<0.01)$, and this was particularly high in the antipyretic treatment group. Despite this, we think that the first treatment option should be tried as antipyretic because there was no association between the type of treatment and time required for fever to reduce as observed for the antipyretic group and the antipyretic and antibiotic combinatorial treatment group.

For their children with fever, it is known that mothers perform a number of traditional practices including removing the children's clothes, making lukewarm shower or making lukewarm application and wiping the body with substances such as water with vinegar. Removing clothes of children is not effective in reducing fever by itself. Making lukewarm application is effective in reducing fever; however, it cannot maintain its fever reducing effect for as long as antipyretics (19). Nevertheless, such methods are also performed by medical staff on the patients who are admitted to emergency services. In our study, we found that $36 \%$ of the mothers performed the peripheral cooling (making lukewarm shower and making lukewarm application) to reduce the fever of their children.

An effect of fever on the lives of the family and the child was on education. In our study, among the children aged seven years and over, we found that 19 children (27.1\%) did not have school absenteeism, while 51 children (72.9\%) was absent from school at least for one day. In the questionnaire named "Assessment of the reasons of absenteeism of students according to student opinions", which was conducted by Şanlı et al. (20), for the question of "Could you provide your reasons for absenteeism?", 42.86\% of the students answered as an acute or a chronic disease. This reminds us again how much precautions are necessary before the disease occurs.

\section{Study Limitations}

First of all, our study was a prospective study with a limited number of patients but was conducted in a restricted time period. Moreover, although the body temperature measurements performed at the first admission of the patients to the emergency service were reliable, mothers were trusted in the home measurements, numerical data were not requested, and the time for fever to reduce and the time for the alleviation of additional complaints were evaluated subjectively according to the mother's responses. In addition, although the date that the study 
was conducted was years ago, the data was re-evaluated over the new sources in the discussion. As of the study period, the limitations of microbiological diagnostic tools led to inability to prove the patient's diagnosis in terms of laboratory results. Today, when considering that emergency services are more advanced than they were on the date of the study, updating data with new studies will contribute more to the literature.

\section{Conclusion}

Fever is still one of the most common complaints among patients admitted to pediatric emergency services. Regardless of their educational status, it also has an ominous feature for all parents. In order to overcome this situation, it is necessary to teach parents about the methods to measure body temperature, to reduce fever and the follow-up fever management with better education programs. It is clear that managing situations regarding fever well will have a positive impact on the child's educational life. Our duty as physicians should be to decrease the frequency of antibiotic prescription. This may be possible by trying antipyretic treatment option before antibiotics in the cases of fever.

\section{Ethics}

Ethics Committee Approval: Ethics committee approval was obtained from ethics committee of the same hospital before the study.

Informed Consent: The informed consents of patients were approved by their parents.

Peer-review: Externally and internally peer-reviewed.

Financial Disclosure: The author declared that this study has received no financial support.

\section{References}

1. Betz MG, Grunfeld AF. 'Fever phobia' in the emergency department: a survey of children's caregivers. Eur J Emerg Med 2006;13(3):129133.

2. Dayal R, Agarwal D. Fever of children and fever of unknown origin. Indian J Pediatr 2016;83(1):38-43.

3. Togoobaatar G, Ikeda N, Ali M, Sonomjamts M, Dashdemberel S, Mori R, et al. Survey of non-prescribed use of antibiotics for children in an urban commity in Mongolia. Bull World Health Organ 2010;88(12):930-936.

4. Hacımustafaoğlu MK, Gürler N, Ünal S. Üst solunum yolu infeksiyonlarının ampirik tedavisinin planlamasında antimikrobiyal direnç: Türkiye ve dünyadaki mevcut durum ve mücadele stratejileri. ANKEM Derg 2018;32(3):109-130.
5. Resi D, Milandri M, Moro M, Romagna E, Study Group on the use of antibiotics in children. Antibiotics prescriptions in children. J Antimicrob Chemother 2003;52(2):282-286.

6. Türkiye İstatistik Kurumu, İstatistiklerle Çocuk 2014;4372:55.

7. Halıcıoğlu O, Koç F, Aşık Akman S, Teyin A. Ateşli çocuklarda; annelerin evde ateşe yaklaşımı, bilgileri ve sosyodemografik özellikler ile ilişkisi. İzmir Dr. Behçet Uz Çocuk Hast Dergisi 2011;1(1):13-19.

8. Şen Celasin N, Ergin D, Atman Ü. Yüksek Ateş Şikayeti İle Hastaneye Yatırılan 0-6 yaş Grubu Çocukları Olan Annelerin Yüksek Ateşe İlişkin Bilgi ve Tutumları. FÜ Sağ Bil Derg 2008;22(6):315-322.

9. Dong L, Jin J, Lu Y, Jiang L, Shan X. Fever phobia: a comparison survey between caregivers in the inpatient ward and caregivers at the outpatient department in a children's hospital in China. BMC Pediatr 2015;15(1):163.

10. Eliaçık K, Kanık A, Oyman G, Rastgel H, Güngör S, Anıl M, et al. Ebeveynlerin ateş hakkında bilgi, inanış ve yanlış uygulamaları. ADÜ Tıp Fakültesi Dergisi 2012;13(1):5-7.

11. Poirier MP, Collins EP, McGuire E. Fever phobia: A survey of caregivers of children seen in a pediatric emergency department. Clin Pediatr 2010;49(6):530-534.

12. Bertille N, Fournier-Charriere E, Pons G, Chalumeau M. Managing fever in children: national survey of parents' knowledge and practices in France. PLoS One 2013;8(12):e83469.

13. Çocuk Acil Tıp ve Yoğun Bakım Derneği. Türkiye'de ve Dünya'da Çocuk Acil Tıp Hizmetleri Mevcut Durum ve Öneriler (2008). http://www.cayd.org.tr.

14. T.C. Sağlık Bakanlığı Kamu Hastaneleri Genel Müdürlüğü İstatistik, Analiz, Raporlama ve Stratejik Yönetim Dairesi Başkanlığı. 'Her branşta ilk 100 hastane' 2017 yılı Ocak-Ekim Dönemi Poliklinik, Yatış, Yoğun Bakım ve Acil Servis İstatistikleri (Aralık, 2017). khgm. istatistik@saglik.gov.tr

15. Zyoud SH, Abu Taha A, Araj KF, Abahri IA, Sawalha AF, Sweileh WM, et al. Parental knowledge, attitudes and practices regarding antibiotic use for acute upper respiratory tract infections in children: A cross-sectional study in Palestine. BMC Pediatr 2015;15(11):176.

16. Boonyasiri A, Thamlikitkul V. Effectiveness of multifaceted interventions on rational use of antibiotics for patients with upper respiratory tract infections and acute diarrhea. J Med Assoc Thai 2014;97(3):S9-13.

17. Özgüneş İ. Akılcı Antibiyotik Kullanımında Hastane Pratiğinde Sorunlar. ANKEM Derg 2005;19(Ek-2):185-189.

18. Ozkurt Z, Erol S, Kadanali A, Ertek M, Ozden K, Tasyaran MA. Changes in antibiotic use, cost and consumption after an antibiotic restriction policy applied by infectious disease specialists. Jpn J Infect Dis 2005;58(6):338-343.

19. Kara B. Çocuklukta ateşle ilgili bilgilerin gözden geçirilmesi. TTB Sürekli Tıp Eğitimi Dergisi 2003;12(1):11.

20. Şanlı Ö, Altun M, Tan Ç. Okula devamsızlık yapan öğrencilerin devamsızlık sebeplerinin öğrenci görüşlerine göre değerlendirilmesi. Elektronik Sosyal Bilimler Dergisi 2015;14(55):161-177. 